\title{
Nurturing lifelong readers
}

\section{Gerri Judkins}

Southwell School, P O Box 14015, Five Cross Roads, Hamilton, 3252, New Zealand. Email gerri.judkins@southwell.school.nz

On reflection, I realise the thing I enjoy most about my job as a school librarian is nurturing lifelong readers, in particular readers of children's literature.

I grew up in a house of many books. My father was interested in New Zealand history and natural history and throughout his 92 years collected books which I feel privileged to have inherited. He fostered my brother Michael's similar interest with Peter Buck's The coming of the Maori, and James Cowan's The New Zealand wars and pioneering period and a book he gave all the grandchildren too, Powell's Native animals of New Zealand. Michael went on to become a prolific journalist, historian and biographer. Of his more than thirty books the first, published in 1972, was Moko: Maori tattooing in the 20th century with photos by Marti Friedlander and the last, in 2003, was The Penguin history of New Zealand. In March 2004 Michael and his wife, Maria, died in a car accident.

Spending time in his office the following month, I found a notebook of quotes he' $\mathrm{d}$ written by hand. One I now keep by my desk at school was "Work shouldn't be something ancillary to your life - but something that nourishes your soul and is a lot of fun!" We are fortunate that as school librarians, our job is both soul nourishing and fun.

In talking about nurturing lifelong readers and, referring to our students, our staff and ourselves - school librarians, I will cover:

- The Southwell Library Programme

- The Lit Club and the Kids' Lit Quiz

- Writers in Schools and the NZ Book Council

- Storylines and The Waikato Children's Literature Association

- SLANZA and IASL

- Studying children's literature and a New Zealand picture book research project

\section{The Southwell Library Programme}

Every week in the Southwell Library is different. Each year we have a theme - 2010 is WHORU? - the pleasure of finding out... I borrowed New Zealand author Vince Ford's style as in his titles 2MUCH4U and SOMUCH2DO. The subtitle came from a science book on my husband's bedside table called The pleasure of finding things out, by Richard Feynman. In introducing the idea, I suggested as well as learning soccer and ballet skills and about people famous in these fields from non fiction, reading fiction about soccer and ballet could help them see ways to cope with disappointments, develop resilience and go on to do better as the book characters do.

Term 1 covers the house keeping, so to speak, the catalogue, the layout of the library, information by the numbers as in Dewey and a survey to assess students' needs and wants. Students may request specific titles, authors, series, non fiction subjects and magazines. The new books in the last week of Term 1 are many of those asked for. More follow in Term 2. I stress to prospective parents viewing the school that the students are part of the buying team. We feature the NZ Post Book Awards. I preview the books then ask the students to vote in the Children's Choice Award considering if they were able to take one of the books home to keep, which would it be? School-wide, the 2010 results: Willie Apiata V C was the most popular with 67 votes followed by Dear Alison and The wonky donkey both with 43 votes. The remaining 400 votes were spread across the other titles, and lots of books were reserved. Nationally the Children's Choice Award was won by The wonky donkey which can be viewed on YouTube, sung by the author Craig Smith.

(C) 2010 IASL, SLAQ and therein by the authors. Diversity Challenge Resilience: School Libraries in Action Proceedings of the $12^{\text {th }}$ Biennial School Library Association of Queensland, the $39^{\text {th }}$ International Association of School Librarianship Annual Conference incorporating the $14^{\text {th }}$ International Forum on Research in School Librarianship, Brisbane QLD Australia, 27 September - 1 October 2010 . 
Term 2 carries on WHORU? with lots of 'I am' weekly themes. For Anzac Day we began with questions about the foyer display, the date we celebrate, Gallipoli, the poppies from France and the importance of picture books in retelling the stories. On the left were four Gallipoli books and Brave Bess and the ANZAC horses by Susan Brocker (written from the horse's point of view). Bess was the only New Zealand ANZAC horse to return form WWI and there were 3,700 sent over in the first shipment alone. I was particularly impressed with the new Australian book Gallipoli: Reckless valour by Nicolas Brasch. The maps made clear the arena of war, which could be referred back to as you read of the assassination of Archduke Ferdinand and the alliances that came into play: Russia with Serbia, France with Russia and England and of course the Commonwealth with England. I linked "Lest we Forget" to memory and the fact the hippocampus, named in 1487 by Julius Caesar Aranzi as it resembled a seahorse, is from the Greek words for sea monster and horse. The hippocampus was only recently proven to be associated with the formation of memories. We then looked at the book Anzac Day parade by Glenda Kane with illustrations by Lisa Allen. I showed how in a sophisticated picture book the words and pictures together convey a more powerful image than either alone. A photo from Michael's New Zealanders at war shows that same paratrooper drop on Crete and I explained that illustrators use such photos as historical reference.

For 'I am History' Years 5-8 students skimmed and scanned the World Book Encyclopedia, reading around the key words for extra information, to find how 12 famous people died gruesome deaths. This was very engaging. We looked at the world, its population and conservation issues, and then books from around the world on the International Children's Digital Library and discussed the e-book issue. The theme 'What makes New Zealand unique?' featured a fun game: guessing Kiwi icons, famous people, inventions and tourist attractions from the clues given. The following week we focused on New Zealand children's literature and how it reflects New Zealand identity and diversity.

To nurture the students' reading journeys I choose to issue books to all the classes who visit weekly. I issue because I can then link readers to other titles, authors or series, make suggestions and reserve books they might like that are currently out.

\section{The Lit Club and the Kids' Lit Quiz}

Here are some of the voracious readers from the Southwell Lit Club. The Club is open to anyone from years 6-8. These students are able to borrow up to 10 books at a time and can have books over the Christmas holidays. At the start of the year we practice for the Kids' Lit Quiz, run by Wayne Mills these past 19 years. The Quiz started in Hamilton and we at Southwell are excited about hosting the international final in 2011. It is 'the sport of reading' and now includes children from China, South Africa and the United Kingdom. Wayne is hoping soon to also take the quiz to Canada and Indonesia. Lit Club members take part in the '4 Million Word Challenge' and the older ones are signed up to Ray Doiron's World Readers. In Book Week we have an inter-house quiz for the seniors and the Lit Club run a junior quiz for years 1-4.

\section{Writers in Schools and the New Zealand Book Council}

In Book Week the highlights are always the visiting authors and Book Character Day. What a wonderful opportunity the NZ Book Council provides for us with the Writers in School programme. The $\$ 80$ annual school membership entitles us to an author for half day with up to $\$ 100$ for travel. Of course for an additional charge you can have them for longer. The newest ideas are 'Speed Dating' and videoconferencing with authors. These experiences nourish us all: students, library staff and teachers alike.

The best prepared and most engaging author we've had was Des Hunt. His first children's novel, A friend in paradise was inspired by a newspaper story about smuggling geckos and the realization a stuffed giant gecko in a Marseille Museum was originally from New Zealand. Here he is shown with a Duvaucel gecko. His presentation featured Frog Whistle Mine. Des' qualification was in atomic chemistry and he set this story near Westport as he wanted the uranium in the area to be a character. He brought a geiger counter and a variety of radio active objects - a real winner. His power point with cartoon characters over photos of the setting was unforgettable. For example, Tony's mother was a cleaner (Mrs Mop) but he wanted her to have a

(C) 2010 IASL, SLAQ and therein by the authors. Diversity Challenge Resilience: School Libraries in Action Proceedings of the $12^{\text {th }}$ Biennial School Library Association of Queensland, the $39^{\text {th }}$ International Association of School Librarianship Annual Conference incorporating the $14^{\text {th }}$ International Forum on Research in School Librarianship, Brisbane QLD Australia, 27 September - 1 October 2010. 
love interest (cartoon of a French Maid). Many of the students who heard him have read every one of his books since and so have the teachers he hooked.

The following year I met author Vince Ford at the airport and was amazed to find he was carrying a spear with just a piece of foam on the tip! Needless to say he hadn't flown Air New Zealand. He highlighted his Chronicles of Stone series which he'd told SLANZA members about back at our 2004 Mini Conference Dinner in Hamilton. You realize the years sometimes involved in the publication of a book. He demonstrated the power of a spear thrower a critical factor in this Stone Age series.

In 2009 Sharon Holt talked about her My Story series books Sabotage (the 1985 sinking of Greenpeace's flagship, the Rainbow Warrior in Auckland Harbour) and No Survivors (the Air NZ Mt Erebus crash). She explained the amount of research that goes into setting a book in the 1970s or the 1980s. In No Survivors Jackie is an ABBA a fan and Sharon showed the children the ABBA memorabilia she purchased on Trade Me. In this series authors can suggest children for the cover illustration, so it was her daughter on No Survivors.

This year we look forward to having Brian Falkner and Diana Neild. Brian is also a web designer so his site is well worth visiting. He has book trailers for The tomorrow code and Brainjack to entice readers which can be used as models for students to create their own. Brian includes his cola taste test (resulting from The real thing in which the Coca Cola recipe is stolen) and an afternoon writing session. Diana recited two of her Piggity-Wiggity stories at the February Hamilton Garden's Festival with local school children playing the pigs dressed in her fabulous costumes. More about Piggity soon...

\section{Storylines and The Waikato Children's Literature Association}

As a member of the Waikato Children's Literature Association and Storylines, I am nurtured by the activities both provide. Storylines, from their website homepage, aims to promote public awareness of the importance of reading and literature for all children; ensure children in New Zealand have access to high quality literature; and support writers and illustrators of literature for children in New Zealand. The Margaret Mahy Medal recognises contribution to the fields of children's literature and literacy and is awarded annually on Margaret Mahy Day. The Tom Fitzgibbon Award is for a work of fiction for $7-13$ year olds by an unpublished author - the prize includes publication by Scholastic. The Joy Cowley Award is for picture book text and the new Gavin Bishop Award for illustration of a given storyboard. You can view the finalists for this on the Random House site. Storylines also publishes a Noteable Books list each year.

The Storylines Family Days in cities around the country in August give thousands of children (and adults!) a chance to meet their literary heroes - authors, illustrators, storytellers or book characters.

Our Waikato Children's Literature Association holds a February AGM with a guest author, hosts the regional Kids' Lit Quiz and enjoys a New Zealand Post Book Awards Night where we review the finalists and predict possible winners. Our annual October seminar draws enthusiasts from a wide area. Last year's first speaker was Paul Tobin from Weta Workshop talking about The crafting of Narnia, a book of the design art work for the movies The lion, the witch and the wardrobe and Prince Caspian. Suzanne Wilson, originally from Melbourne, has been Li Cunxin's editor these past ten years and part of the creation of Mao's last dancer, the young readers edition and the picture book, The peasant prince. She outlined the process of biography to picture book showing e.g. photos taken in China by the illustrator Anne Spudvilas and one of the original artworks, the scene of the Beijing railway station. This year's seminar is "Picture New Zealand" with Des Hunt, mentioned before, Maria Gill and illustrator, Vivienne Lingard. Maria's book Rangitoto is a finalist in the 2010 New Zealand Post Book Awards. This volcanic island in Auckland Harbour is only 600 years old. Maria and Vivienne have worked together on Save our Seas and eco-rangers save the planet. 


\section{SLANZA and IASL}

SLANZA, the School Library Association of New Zealand Aotearoa is ten years old. When it was one, we hosted the IASL Conference in Auckland. SLANZA offers members regional professional development and a biennial national conference. New Zealand school librarians chatter daily on the Lib Listserv, providing answers to questions, supplying missing pages or links to needed resources and resulting lists are complied on the SLANZA wiki. We are a small country, both in size and population, so we feel very connected and nurture each other and subsequently all our students. We visit each others libraries at every opportunity and it was in Kerikeri I got the idea to photograph all the staff reading.

IASL has added a more global dimension to my view of school libraries and I was nourished by the 2009 Conference in Italy. On the day trip to Venice with Martine and Donatella we visited the Marciana Library founded in 1468 to house the 750 Greek and Latin codices gifted by Cardinal Bessarion. I appreciated that Italians value antiquity in books as well as art and architecture. Another canal trip took us to Ca Foscari, the university education library in Dorsoduro where we were hosted by Alessandro Bertoni. We had a wonderful lunch with Prosecco and I was amazed to see Jane Eyre by Currer Bell and an 1888 edition of Hodgson Burnett's Sarah Crewe.

From the IASL/IFLA joint meeting, Reading in the Digital Age, I have used Guido Petter's six aspects of children's psychological development that are enhanced by reading. He cited examples from folklore and classics. Aidan Chamber's comment "Children need to hear a word read aloud before they can learn to read it" stayed with me and was the basis for a feature using Diana Neild's Piggity-Wiggity jiggity jig goes to dad's café. I first showed words e.g. disarray, various, belligerent, repercussions, resplendent, aplomb and auspicious in isolation and asked the children to read and define them, with varying success. Then we read the book and all was made clear.

\section{Studying children's literature and the research project}

I have slowly, one paper a year, been working towards a Diploma in Children's Literature from Canterbury University and finding each paper is immediately relevant to nurturing budding readers. Image and narrative focused on the form and nature of text and illustration in picture books and I have shared the features of illustration again this year. Patterns of language was poetry from doggerel, playground chants and nursery rhymes, through ballads, narrative poems, blank verse, cautionary poems, and haiku etecera. It was a great opportunity to update the poetry section and be a more informed resource for teachers. Story and meaning with mythology, folklore, fables and literary fairy tales was wonderful. Things I didn't know I didn't know, I could pass on to the students right away.

This year I am doing The New Zealand experience. The initial question was "What was the first book you recall recognising as a New Zealand book?" For me, it was Opo: the gay dolphin by Avis Acres published in 1956. As I collect New Zealand children's books, this course is a joy. Sadly the qualification is no longer available for enrolment. Those part-way through have until 2016 to complete. Interesting requirements that could be applied to children's literature in other countries also are:

- List New Zealand books for children with earthquakes or volcanoes. What effect of 'eeriness' might this hold for the non New Zealand reader?

- Recognise conservation problems and solutions in children's literature.

- List distinctive New Zealand expressions found in New Zealand children's books with bibliographic details.

- Which customs and concerns make New Zealand unique?

I am also involved in a research project with Nicola Daly from Waikato University. Following the work of Joyce Bainbridge from Alberta, we selected a group of picture books that will represent New Zealand identity and diversity. It was a very challenging and pleasurable exercise. Six of us involved in the field of children's literature in Hamilton, including an author, brought and shared books over four sessions. We then 
had to look at the recommendations and identify gaps e.g. diverse ethnicity. When finalised, this collection will be used in teacher training at Waikato University.

Lastly, on a serious note, near the end of 2009 I nurtured responsible reading by featuring the importance of referencing. I created a power point that began the way of dvd rental warnings about theft. My end of year thank you letter (actual spelling) from a seven year old student was a delight.

"Thank you Mrs. Judkins for teaching me and my class 3BB about stealing and plagiarism. Your sincerily Harrison Stace".

This letter was one of the many rewards of nurturing lifelong readers.

\section{References}

Acres, A. (1956). Opo: the gay dolphin. Wellington: A.H. \& A. W. Reed.

Brasch, N. (2009). Gallipoli: Reckless valour. Fitzroy, VIC: Black Dog.

Brocker, S. (2010). Brave Bess and the ANZAC horses. Auckland, NZ: Harper Collins.

Brown, B. (2005). A booming in the night (Illus. H. Taylor). Auckland, NZ: Reed.

Browne, A. (2003). The shape game. London: Doubleday.

Cowley, J. (2009, 1982). The terrible taniwha of Timberditch (Illus. R. McRae). North Shore, NZ:

Puffin.

Crew, G. (2008). Cat on the island (Illus. G. Warden). Sydney, NSW: Harper Collins.

Cunxin, L. (2007). The Peasant prince (Illus. A. Spudvilas). Camberwell, Vic: Viking.

Drewery, M. (2006). Dad's takeaways (Illus. C. White). Wellington, NZ: Mallinson Rendell.

Dunlop, B. (1984). Earthquake town. Auckland, NZ: Hodder \& Stoughton.

Falconer, D. The crafting of Narnia : the art, creatures and weapons from Weta workshop. New York, NY : HarperOne : Weta Pub.

Falkner, B. (2009). Brainjack. Newtown, NSW: Walker Books Australia.

Falkner, B. (2008). The tomorrow code. Newtown, NSW: Walker Books Australia.

Ford, V. (2010). Jonty and Choc: a story. Auckland, NZ: Scholastic.

Ford, V. (2008). Scorched bone. Auckland, NZ: Scholastic.

Gill, M. (2009). Eco-rangers save the planet (Illus. V. Lingard). Auckland, NZ: New Holland.

Gill, M. (2009). Rangitoto (Illus H. Arnold). Auckland, NZ: Puffin Books.

Gill, M. (2009). Save our seas (Illus. V. Lingard). Auckland, NZ: New Holland.

Grace, P. (1984). Watercress tuna and the children of Champion Street (Illus. R. Kahukiwa). Auckland, NZ: Longman Paul.

(C) 2010 IASL, SLAQ and therein by the authors. Diversity Challenge Resilience: School Libraries in Action Proceedings of the $12^{\text {th }}$ Biennial School Library Association of Queensland, the $39^{\text {th }}$ International Association of School Librarianship Annual Conference incorporating the $14^{\text {th }}$ International Forum on Research in School Librarianship, Brisbane QLD Australia, 27 September - 1 October 2010. 
Hill, D. (2001). The sleeper wakes. Auckland, NZ: Penguin.

Holt, S. (2006). It's true! You can make your own jokes (Illus. R, Kinkaid). Crows Nest, N.S.W.: Allen \& Unwin.

Holt, S. (2009). No survivors. Auckland, NZ: Scholastic.

Holt, S. (2008). Sabotage. Auckland, NZ: Scholastic.

Hunt, D. (2009). Cry of the taniwha. Auckland, NZ: Harper Collins.

Hunt, D. (2002). A friend in paradise. Auckland, NZ: Harper Collins.

Hunt, D. (2006). Frog whistle mine. Auckland, NZ: Harper Collins.

Hunter, E. 1999. The quake. Auckland, NZ: Scholastic.

Kane, G. (2010). Anzac Day parade (Illus. L. Allen). North Shore, NZ: Puffin.

King, M. (1981). New Zealanders at war. Auckland, NZ: Heinemann.

Lightfoot, K. (2008). Every second Friday (Illus. B. Galbraith). London: Hodder Children’s.

Little, P. \& Lockyer, J. (2009). Willie Apiata, VC: the reluctant hero. Auckland, NZ: Puffin.

Long, D. (2004). The lacquer box (Illus. V. Lingard). Auckland, NZ: Reed.

McMillan, D. (2005). Weaving together (Illus. V. Lingard). Auckland, NZ: Reed.

Muff, D. (2009). Dear Alison: a New Zealand soldier's story from Stalag 383. North Shore, NZ:

Penguin.

Neild, D. (2009). Piggity-Wiggity wiggity goes to dad's café (Illus. P. Webb). Auckland, NZ: Scholastic.

Smith, C. (2009). The wonky donkey (Illus. K.Cowley). Auckland, NZ: Scholastic.

Tipene, T. (2004). Haere: Farewell Jack, farewell (Illus. H. Smith). Wellington, NZ: Huia Publishers.

Tua'koi, F. \& Unka, V. (2008). He aha te ngārara? Auckland, NZ: Scholastic.

Tua'koi, F. \& Unka, V. (2007). What is a fish? Auckland, NZ: Scholastic.

(C) 2010 IASL, SLAQ and therein by the authors. Diversity Challenge Resilience: School Libraries in Action Proceedings of the $12^{\text {th }}$ Biennial School Library Association of Queensland, the $39^{\text {th }}$ International Association of School Librarianship Annual Conference incorporating the $14^{\text {th }}$ International Forum on Research in School Librarianship, Brisbane QLD Australia, 27 September - 1 October 2010. 